Historic, archived document

Do not assume content reflects current scientific knowledge, policies, or practices. 
MOISTURE CONTENT OF

LUMBER PRODUCED FROM

DEAD WESTERN WHITE PINE AND

LODGEPOLE PINE TREES

David P. Lowery

Allen L. Hearst, Jr.
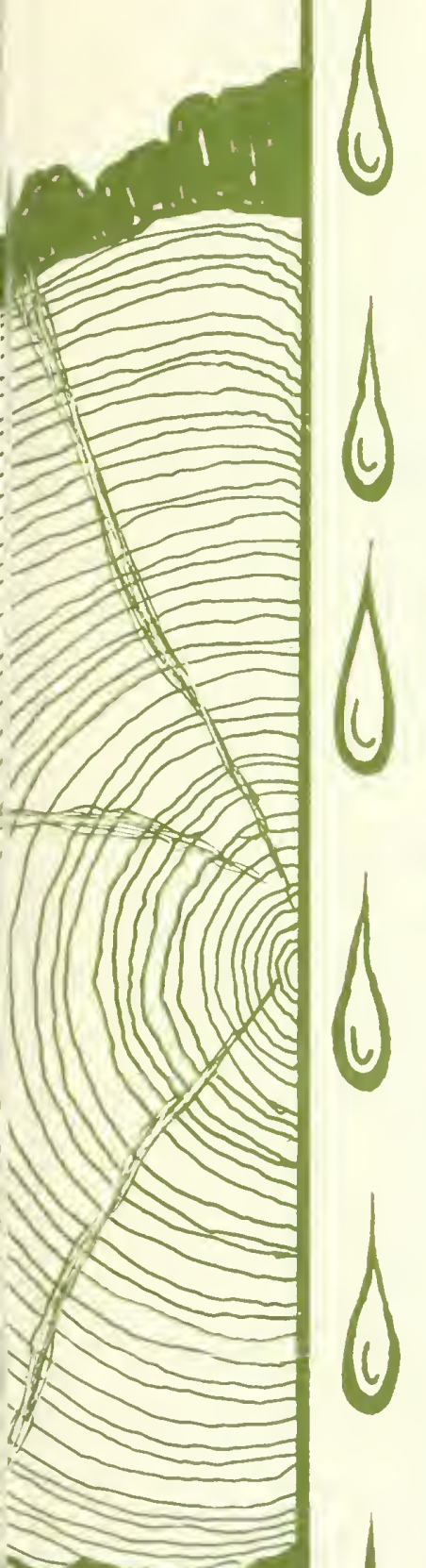

$\cdots, i j^{a+1 / 1 / 1 / 1}$
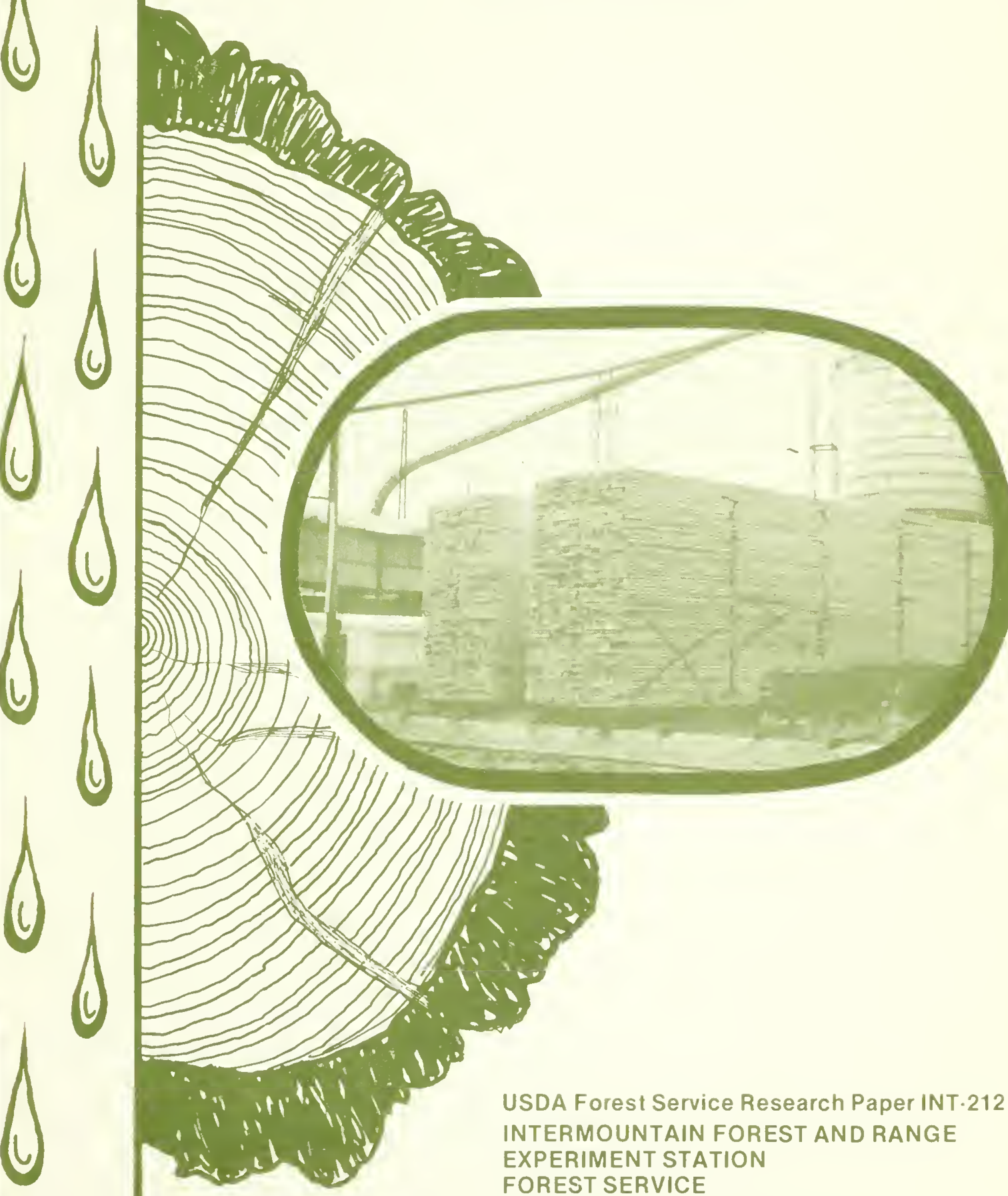

USDA Forest Service Research Paper INT.212 INTERMOUNTAIN FOREST AND RANGE EXPERIMENT STATION FOREST SERVICE

U.S. DEPARTMENT OF AGRICULTURE 
USDA Forest Service

Research Paper INT-212

July 1978

\title{
MOISTURE CONTENT OF LUMBER PRODUCED FROM \\ DEAD WESTERN WHITE PINE AND \\ LODGEPOLE PINE TREES
}

\author{
David P. Lowery and Allen L. Hearst, Jr.
}

INTERMOUNTAIN FOREST AND RANGE EXPERIMENT STATION

Forest Service

U.S. Department of Agriculture

Ogden, Utah 84401 


\section{THE AUTHORS}

DAVID P. LOWERY is Wood Technologist, stationed at the Intermountain Station's Forestry Sciences Laboratory in Missoula, Montana.

A LLEN L. HEARST, JR. is Utilization Specialist with State and Private Forestry, Cooperative Forest Management Branch, Northern Region, Missoula, Montana.

\section{ACKNOWLEDGMENT}

The authors gratefully acknowledge the assistance and cooperation provided by the Diamond International Corporation of Coeur d'Alene, Idaho, and the Idaho Stud Company of St. Anthony, Idaho. Robert Nix and Donald Walters, both of Diamond, and Gordon Wilson, of Idaho Stud, were especially helpful. Their courtesies and suggestions during the collection of data are appreciated. 


\section{CONTENTS}

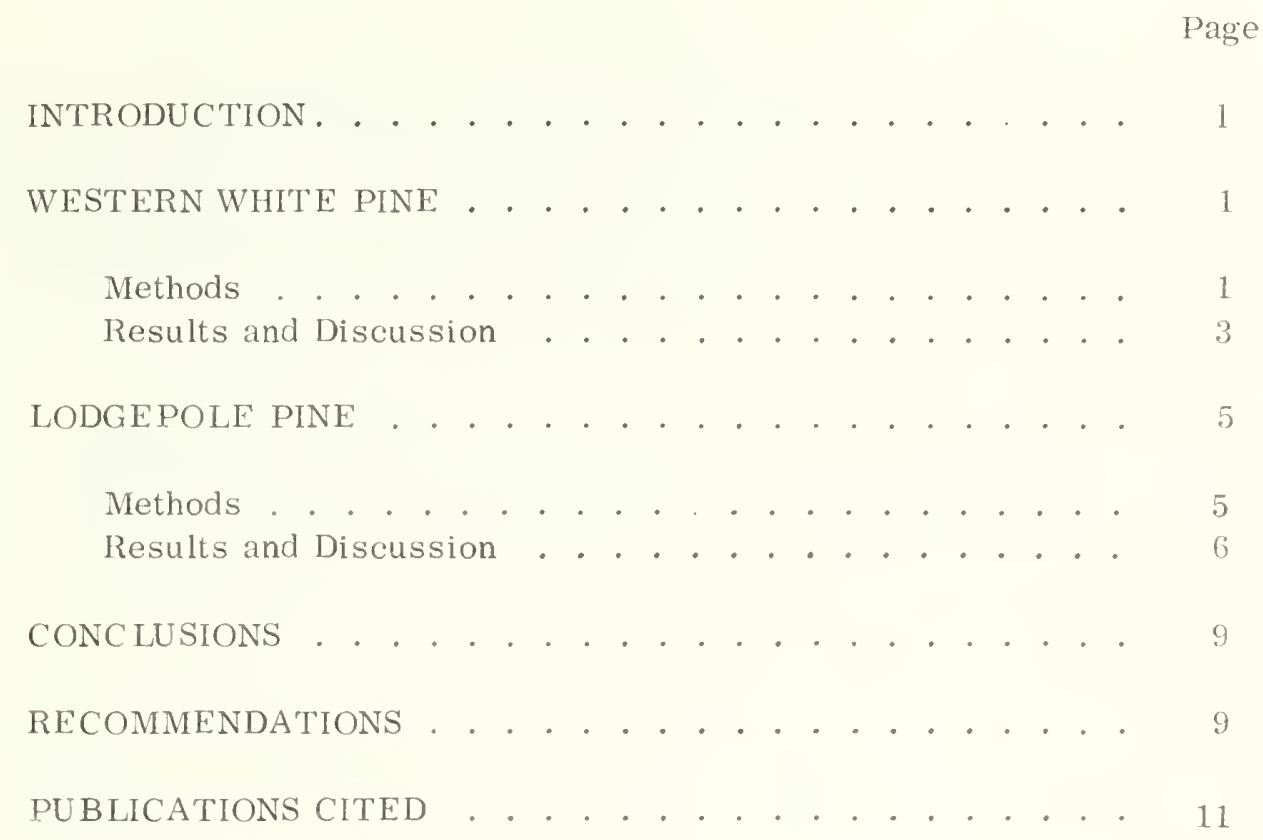




\section{RESEARCH SUMMARY}

One of the Rocky Mountain area's major problems is the utilization of insect- and disease-killed timber. More and more of these trees are being harvested as a part of green timber sales. The efficient handling and processing of this material depends to a large extent on its moisture content.

In the two studies reported here, the moisture content of lumber sawed from dead western white pine and lodgepole pine logs was determined using both a moisture meter and the ovendry test method. In both studies the moisture content of lumber from dead trees was about half that reported for green lumber of the same species. Test sections cut from a sample of the boards showed that the dead log lumber had essentially no moisture gradient and only a slight amount of drying stress.

This information indicates the kiln drying time for dead log lumber should be about half the time required to dry green lumber. A dry kiln operator can determine the appropriate drying conditions for a charge of dead lumber by measuring its moisture content with a moisture meter. 


\section{INTRODUCTION}

Within recent years, disease and insects have killed numerous western white pine (Pinus monticola Dougl.) and lodgepole pine (Pinus contorta var. Zatifolia Engelm.) trees in the timber stands of Idaho and Montana. Estimates place the annual mortality of all softwood species in these two States at about 350 million cubic feet and for western white pine alone at 60 million cubic feet. About 10 percent of the dead trees is salvaged as a part of ongoing timber sales. The logs from these trees are usually processed with green logs and the lumber is intermixed for drying and surfacing.

This practice may not be the best since the lumber from the dead trees usually has a much lower moisture content than the lumber made from green logs. With everincreasing energy costs, the present procedure is uneconomical with longer kiln dwell time than is necessary for the lumber from the dead logs and excessive degrade of this material by overdrying.

The objective of this study was to determine the moisture content, before drying, of lumber made from dead white pine and lodgepole pine logs. The moisture content was measured using both a moisture meter and the standard ovendry test. The results were compared to determine accuracy and consistency between the two methods. Small sections cut from sample lumber were tested for moisture gradient and drying stress. In addition, a few moisture meter readings were obtained from the lodgepole pine studs after kiln drying. This information was used to evaluate the drying methods and determine if changes would be desirable. Each of the study species was processed at a single mill and the results of the two studies are discussed separately.

\section{WESTERN WHITE PINE}

\section{Methods}

A sawmill in north Idaho was selected for the white pine study. The mill's procedure was to segregate the dead tree logs in the mill yard and when a sufficient volume had been accumulated, process the $\operatorname{logs}$ in 1 or 2 days' time. The mill, equipped with a circular saw, cut dead logs into dimension lumber, primarily 2 by $4^{\prime} \mathrm{s}$ and 2 by $6^{\prime} \mathrm{s}$, with a few 1 inch sideboards being produced as well. On the green chain, the lumber, of random length, was box piled and stickered for kiln drying. 
Four packages of lumber were selected at the green chain for study. Three of the packages were 2 by 4 's and a fourth was 2 by 6's, reflecting the approximate proportion of a day's production. The moisture content was measured with a resistance-type meter equipped with a four-needle, 1/2-inch-long probe. Three moisture meter readings were taken from each board in the sample packages approximately 2, 6, and 10 feet from one end. Later the moisture meter readings were adjusted for temperature and an average reading for each board calculated. In addition, a subsample containing 10 boards from package No. 2, 9 boards from package No. 3, and 6 boards from package No. 4 was selected at random for destructive sampling. Package No. I was not available at the time this subsample was selected so packages 2 and 3 were more heavily sampled than package 4 to make up for this deficiency.

Four pieces, approximately 20 inches long, were cut from each of the subsample boards. The pieces were cut 2 and 6 feet from each end of the board. These pieces, identified as to board, were placed in polyethylene bags and carried to the shop where three sections about an inch long, were cut from near the center of each piece (fig. 1).

The first section of each board, which we labeled the A sections, was left intact and used to determine the moisture content by the standard ovendry test. The B sections were further cut into shells and cores (fig. lB) and used to determine the moisture distribution by the ovendry method. The C sections were sliced into four prongs (fig. 1C) and placed on a table in the shop where they were permitted to dry at room temperature. These drying stress sections were examined periodically to determine the presence of any casehardening or reverse casehardening.

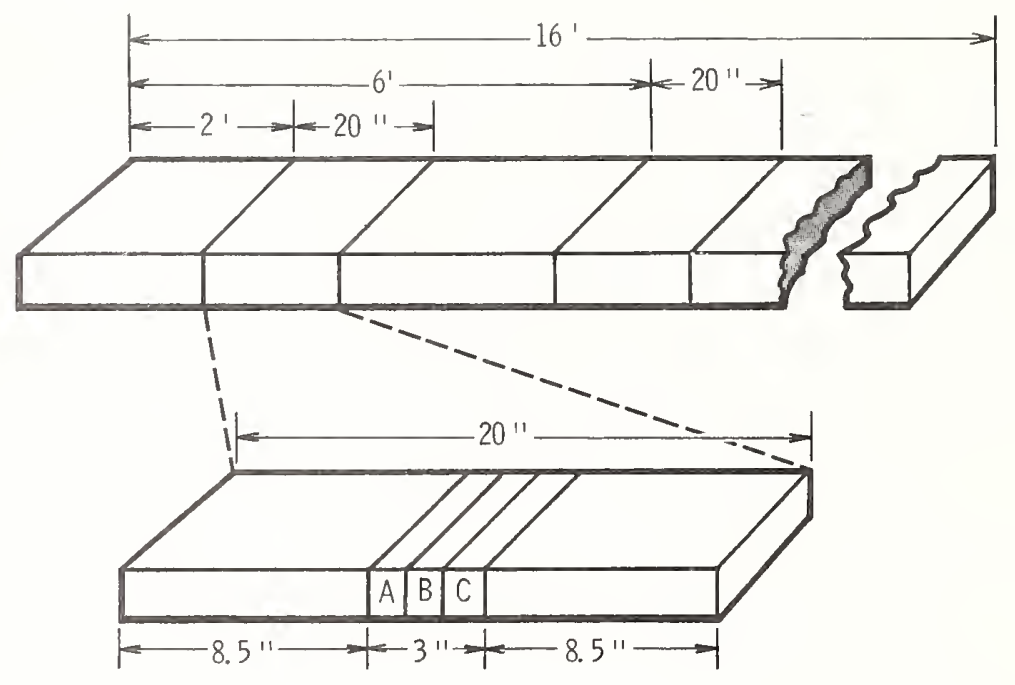

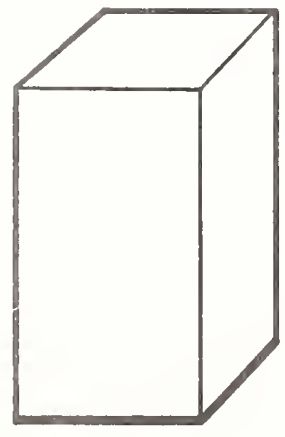

A

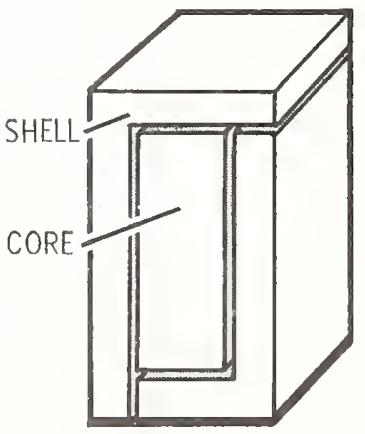

B

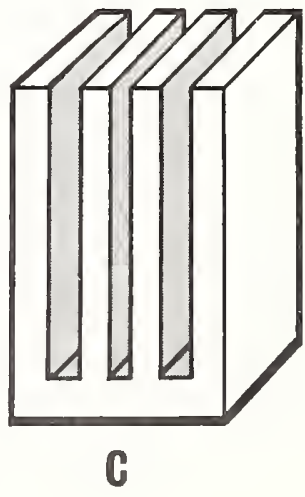

Figure 1.--Schematic showing how board pieces and sections were cut. Sections $A, B$, and $C$ are end views; $A$ is moisture content section, $B$ is moisture distribution section, and $C$ is drying stress section. 


\section{Results and Discussion}

The temperature-corrected moisture meter readings indicated that the average moisture content of all the boards in the four packages was 23.7 percent, with the values ranging from 15 to 31 percent (table 1). The ranges in moisture contents for the various packages show that the values were fairly consistent. The average percent moisture contents for the individual packages were $20.8,23.1,26.7$, and 25.1 , respectively.

A sumnary of the moisture content and moisture distribution sections (A and $B$ specimens), averaged by packages, is shown in table 2. These values show that the difference in percent moisture content between the shell and core was slight. This is as expected--the boards were newly sawed and had had no opportunity to dry. Likewise the difference in moisture content of the three specimens was slight. The greatest difference was 1.7 percent for package No. 3 .

Table 1.--Sumary of the moisture meter values ${ }^{1}$ for dimension Zumber produced from dead western white pine logs

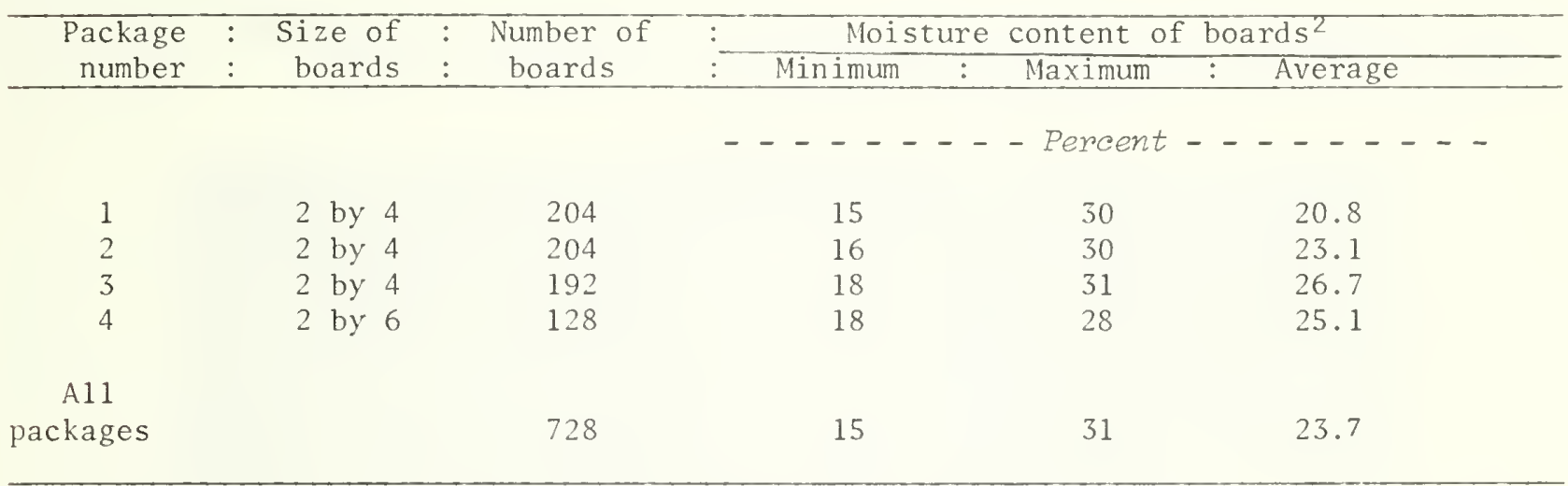

I The moisture meter readings were corrected for temperature.

${ }^{2}$ The average of at least three moisture meter readings taken on each board was used for the moisture content of that board.

Table 2.--Sumary of actual moisture content (ovendry method) of test sections $A$ and $B$ cut from lumber of dead western white pine logs

\begin{tabular}{|c|c|c|c|c|c|c|c|c|}
\hline \multirow{3}{*}{$\begin{array}{r}\text { Package } \\
\text { number }\end{array}$} & \multirow{3}{*}{$\begin{array}{l}: \\
\vdots \\
:\end{array}$} & \multirow{3}{*}{$\begin{array}{l}\text { Number of } \\
\text { boards } \\
\text { in subsample }\end{array}$} & \multirow[b]{3}{*}{ Size } & \multicolumn{5}{|c|}{ Average moisture content } \\
\hline & & & & \multirow{2}{*}{ A sections } & \multicolumn{4}{|c|}{ B sections } \\
\hline & & & & & She11 & 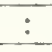 & Core & \\
\hline & & & & -- & ercent - & & - & - \\
\hline 2 & & 10 & 2 by 4 & 26.3 & 27.6 & & 27.3 & \\
\hline 3 & & 9 & 2 by 4 & 28.4 & 27.9 & & 29.6 & \\
\hline 4 & & 6 & 2 by 6 & 29.2 & 30.3 & & 30.9 & \\
\hline
\end{tabular}


For package No. 2, the average moisture content derived from the ovendry test was 4.2 percent higher than the moisture meter average; 2.9 percent higher for package 3; and 5.8 percent higher for package 4. These increases might be attributed to the reduced reliability of moisture meter readings above 25 percent and the fact that the meter readings were not corrected for species (James 1975). A relationship between moisture values obtained from meter readings and the ovendry method is discussed under "Recommendations."

The drying stress sections indicated that only minor stresses were present. The prongs on 61 of these specimens remained straight, on 26 specimens there was a slight degree of casehardening (prongs turned inward) and on 6 specimens there was a slight reverse casehardening (prongs turned outward) (fig. 2). The turning of the prongs inward indicated that some tension set had developed and turning of the prongs outward would occur only when wood below 30 percent moisture content was rewet.

For green western white pine, the Wood Handbook (Forest Products Laboratory 1974) lists values of 62 and 148 percent moisture content for heartwood and sapwood, respectively. The average moisture content by oven test of our wettest test package is about half of the moisture content value for green heartwood; so a drying time about half as long should be expected. The low moisture content should also enable the wood to withstand a higher initial dry bulb temperature than could be used with green wood. With this more severe drying schedule, the initial wet bulb depression should be minimal in order to reduce the development of drying stresses (McMillen 1968).

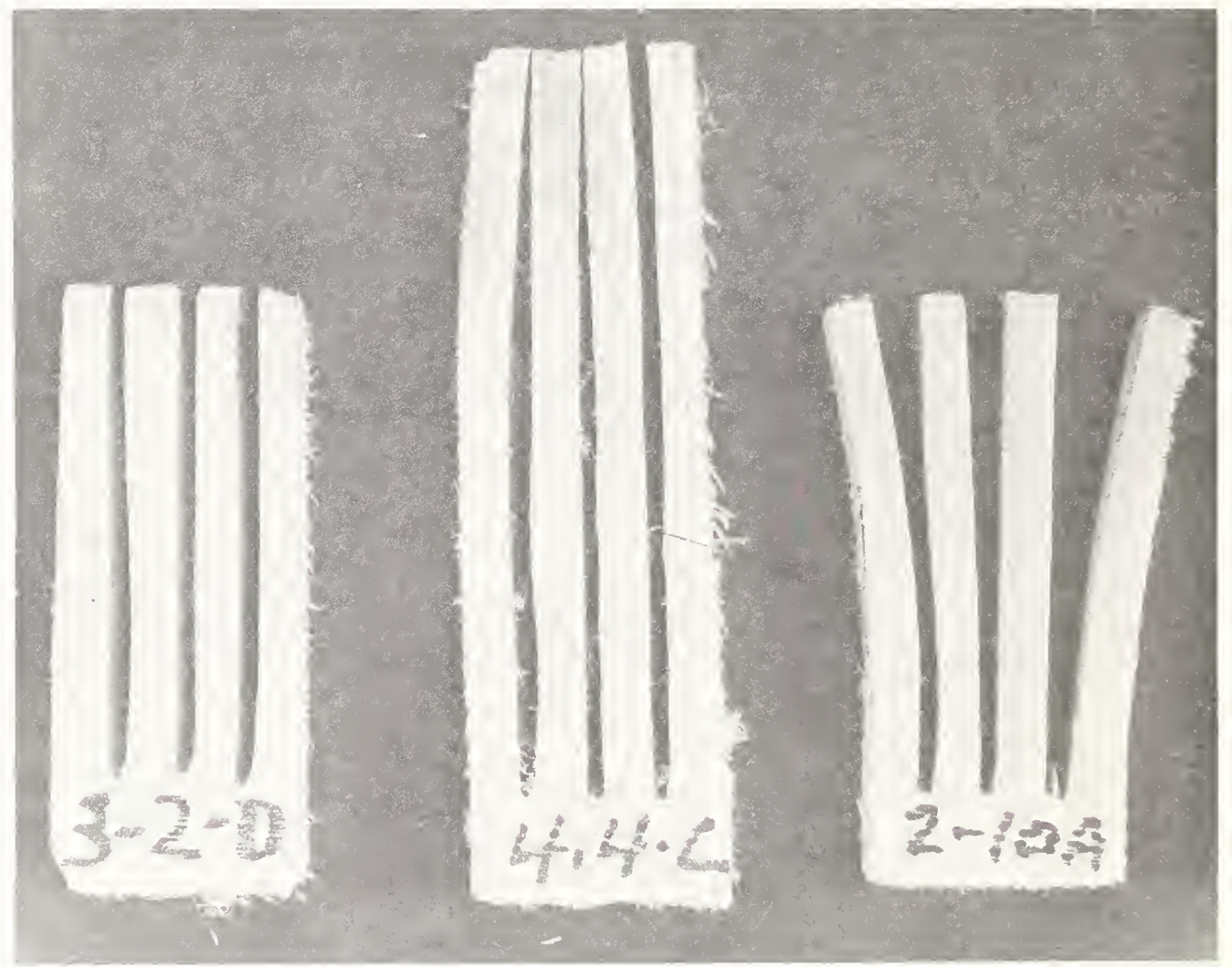

Figure 2.--Photo of typical drying stress sections obtained from boards in package No. 3, 4, and 2. The center figure shows casehardening; the figure on the right shows reverse casehardening. 
For the mill that produces a quantity of dead lumber, some experimentation will probably be necessary to determine the optimum drying conditions. The white pine study mill was equipped with a high temperature kiln. The mill has settled on the practice of using an initial dry bulb temperature of $190^{\circ} \mathrm{F}$ with a wet bulb depression of $30^{\circ} \mathrm{F}$. During the winter months when the logs and lumber are high in moisture content or are frozen, these drying conditions are maintained for 24 hours. During the summer months, and especially if there is a delay between piling and drying, the kiln time is reduced to 12 hours, but the same drying conditions are used. Whether these are optimum drying conditions is not known, but the mill reports no planer split or other drying degrade as a result of these schedules.

\section{LODGEPOLE PINE}

\section{Methods}

The second study, on lodgepole pine, was conducted at a mill in southeastern Idaho. This mill obtains most of its logs from the Targhee National Forest which has been the site of an epidemic infestation by the mountain pine beetle, Dendroctonus ponderosae (Hopk.). Over the past two decades, this insect has been responsibie for killing an estimated 2 billion board feet of lodgepole pine timber on this Forest. Some of this dead timber has been purchased by the study mill.

The mill is equipped with a small headrig for breaking down logs over 14 inches in diameter and a quad-band mill for sawing logs under 14 inches. Edgers are used to cut the cants into 2 by 4 's. Only studs and a few 1 by 4 sideboards are produced. This limited number of products eliminates the necessity for a green chain, instead the lumber is stickered and piled on kiln trucks for drying at the back end of the mill.

For this study a sufficient number of dead logs were processed through the mill to produce two kiln trucks of studs. The logs were debarked, cut to length, and fed into the mill. A measuring station was established at the midpoint of the chain carrying the studs to the stacker. At this station, the moisture content of a random sample of the studs was determined using the same moisture meter used in the earlier study. The speed of the chain and the desire to sample as many studs as possible precluded the use of all the meter scales; instead only the 12 to 22 percent moisture content scale was used. Those studs having a moisture content greater than 22 percent were recorded as having the scale maximum. In addition, 22 studs were pulled from the chain for destructive sampling. At the completion of the mill run a 2 -foot-long piece was cut from the center of these studs and saved for later preparation of test sections.

Three test sections, approximately 1 inch long were cut from near the center of each piece as in the earlier study (fig. 1). These sections, again labeled A, B, and $\mathrm{C}$, were used for determining moisture content, moisture distribution, and drying stress.

After determining their moisture content, the studs were piled for drying in the automatic stacker. The two kiln trucks of dead tree studs accumulated during the study were identified and dried in a single kiln charge along with six trucks of green studs. 
The regular green drying schedule was used to dry the charge. This 98-hour schedule uses an initial dry-bulb temperature of $160^{\circ} \mathrm{F}$, a final temperature of $180^{\circ} \mathrm{F}$, and includes two 3 -hour steaming periods. The initial wet-bulb depression was $10^{\circ} \mathrm{F}$, and the final depression was $90^{\circ} \mathrm{F}$.

After drying, the studs were surfaced and bundled for shipment. The moisture meter was used to obtain a sample of moisture readings as the studs were being packaged.

\section{Results and Discussion}

The moisture content of slightly more than half of the studs (1,658 of about 3,050 ) cut from dead lodgepole pine logs was measured with a moisture meter in the sawmill. One reading was obtained from the approximate center of each piece. The average of these meter readings was 16.5 percent. However, the true value is probably somewhat higher than this value as 225 (approximately 14 percent) of the readings were above 20 percent and undoubtedly some of these values exceeded the maximum of the meter scale used. The readings were not corrected for temperature or species. The distribution of the readings is shown in figure 3.

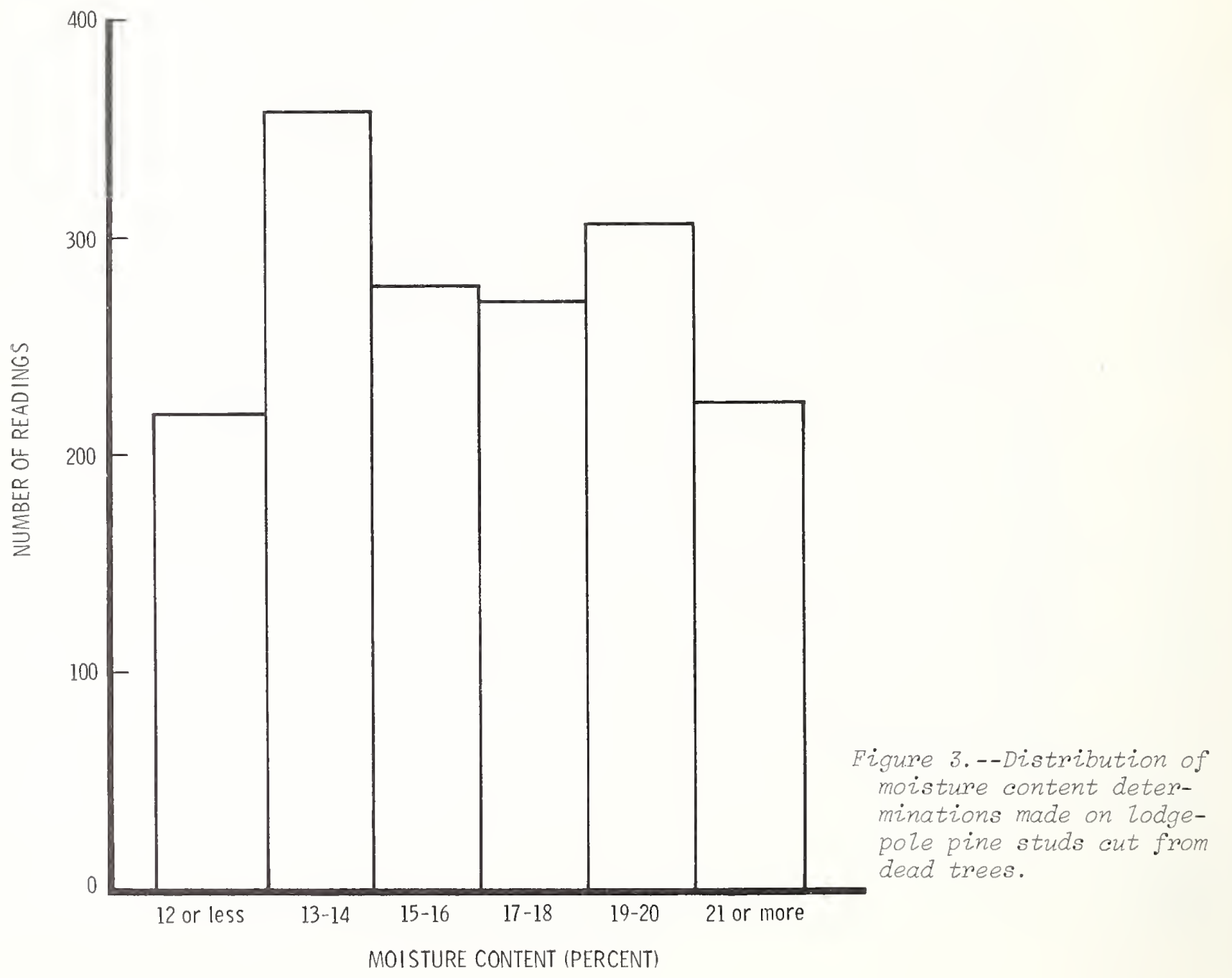


Table 3.-Moisture content of test sections $A$ and $B$ cut from studs of dead lodgepole pine logs

\begin{tabular}{|c|c|c|c|c|c|}
\hline \multirow{2}{*}{$\begin{array}{l}\text { Sample stud } \\
\text { number }\end{array}$} & \multirow{2}{*}{$: \quad$} & \multirow[b]{2}{*}{ sections } & \multicolumn{2}{|c|}{$\mathrm{B}$ sections } & \multirow{2}{*}{$\begin{array}{c}\text { Weighted average for } \\
\text { stud }\end{array}$} \\
\hline & & & She11 & : Core & \\
\hline & - - & $\ldots$ & $-\ldots--$ & Percent - & $\ldots-\ldots-\ldots$ \\
\hline 1 & & 16.7 & 16.7 & 16.3 & 16.6 \\
\hline 2 & & 19.3 & 18.8 & 18.6 & 19.0 \\
\hline 3 & & 17.0 & 18.1 & 17.1 & 17.4 \\
\hline 4 & & 16.8 & 15.9 & 16.0 & 16.4 \\
\hline 5 & & 25.1 & 23.5 & 26.3 & 24.9 \\
\hline 6 & & 28.7 & 26.7 & 29.2 & 28.2 \\
\hline 7 & & 18.6 & 18.3 & 19.1 & 18.6 \\
\hline 8 & & 23.7 & 23.5 & 25.5 & 24.0 \\
\hline 9 & & 32.3 & 28.4 & 32.7 & 31.2 \\
\hline 10 & & 19.3 & 18.2 & 18.5 & 18.8 \\
\hline 11 & & 34.3 & 30.2 & 33.3 & 32.9 \\
\hline 12 & & 43.7 & 39.6 & 36.8 & 41.1 \\
\hline 13 & & 23.7 & 21.3 & 24.1 & 23.1 \\
\hline 14 & & 19.4 & 19.1 & 19.7 & 19.4 \\
\hline 15 & & 16.7 & 15.3 & 15.8 & 16.1 \\
\hline 16 & & 20.9 & 19.6 & 20.8 & 20.5 \\
\hline 17 & & 25.1 & 24.4 & 27.2 & 25.3 \\
\hline 18 & & 18.7 & 17.6 & 17.6 & 18.2 \\
\hline 19 & & 24.3 & 23.2 & 26.0 & 24.3 \\
\hline 20 & & 15.6 & 15.4 & 14.6 & 15.3 \\
\hline 21 & & 23.0 & 22.0 & 24.6 & 23.0 \\
\hline 22 & & 26.1 & 24.6 & 26.7 & 25.8 \\
\hline MEAN & & 23.1 & 21.8 & 23.0 & 22.7 \\
\hline
\end{tabular}

${ }^{1}$ Computed by multiplying the shell moisture content by 12 , the core moisture content by 8 , and the average moisture content (section A) by 20. The sum of these values was divided by 40 .

The distribution of the moisture content of test sections A and B (moisture content and moisture distribution specimens) is shown in table 3 . The average moisture content for the A sections was 23.1. The average for the shells of the B sections was 21.8 ; and for the cores 23.0 .

Because of the variation in the lodgepole pine test sections and to obtain a reliable estimate of moisture content, a weighted average moisture content was computed. This value was calculated by multiplying the shel1 moisture content by 12 , the core moisture content by 8 , and the moisture content of section A by 20 . The sum of these values was divided by 40 to obtain the weighted average moisture content. The computed values for the sample studs ranged from 15.3 to 41.1 percent and 12 of the 22 average values exceeded 20 percent (table 3 ). The maximum difference between the shell and core was 4.3 percent, and the average difference was 1.2 percent moisture content. Five of the shells had a slightly higher moisture content than the core. This is contrary to expectation and indicates some reabsorption of moisture.

Three of the 22 drying stress test sections showed a slight amount of casehardening or tension set. McMillen (1968) has shown that tension set develops from the start of drying and often reaches a maximum above 30 percent average moisture content. The 
uniformity of moisture content and the lack of tension set indicate that any drying schedule for dead tree studs should not have too large an initial wet-bulb depression in order to minimize the development of drying stresses.

As before, the moisture content values obtained from the moisture meter were lower than those obtained from the ovendry tests. This discrepancy is probably due to the single meter scale used and the number of readings that exceeded the scale maximum. In general, the results of both the moisture meter readings and the ovendry determinations show that the moisture content of the studs is fairly uniform and less than 30 percent. This unifomly low moisture content indicates that the studs obtained from dead trees should dry in about half the time required for studs from green trees, which have an average heartwood moisture content of 41 percent and a sapwood moisture content of 120 percent (Forest Products Laboratory 1974).

After the dead tree studs had been dried and surfaced, the moisture content of a number of studs was remeasured with a moisture meter. The average moisture content of these studs was only 8.2 percent and the maximum value was 21 percent (fig. 4). A large percentage of the studs was in the 8 percent or lower moisture content class which suggests that when a small amount of dry material is included in a charge of green material, the final equilibrium moisture content should be about 6.5 percent. This would be especially desirable to avoid overdrying in wider boards subject to planer splitting.

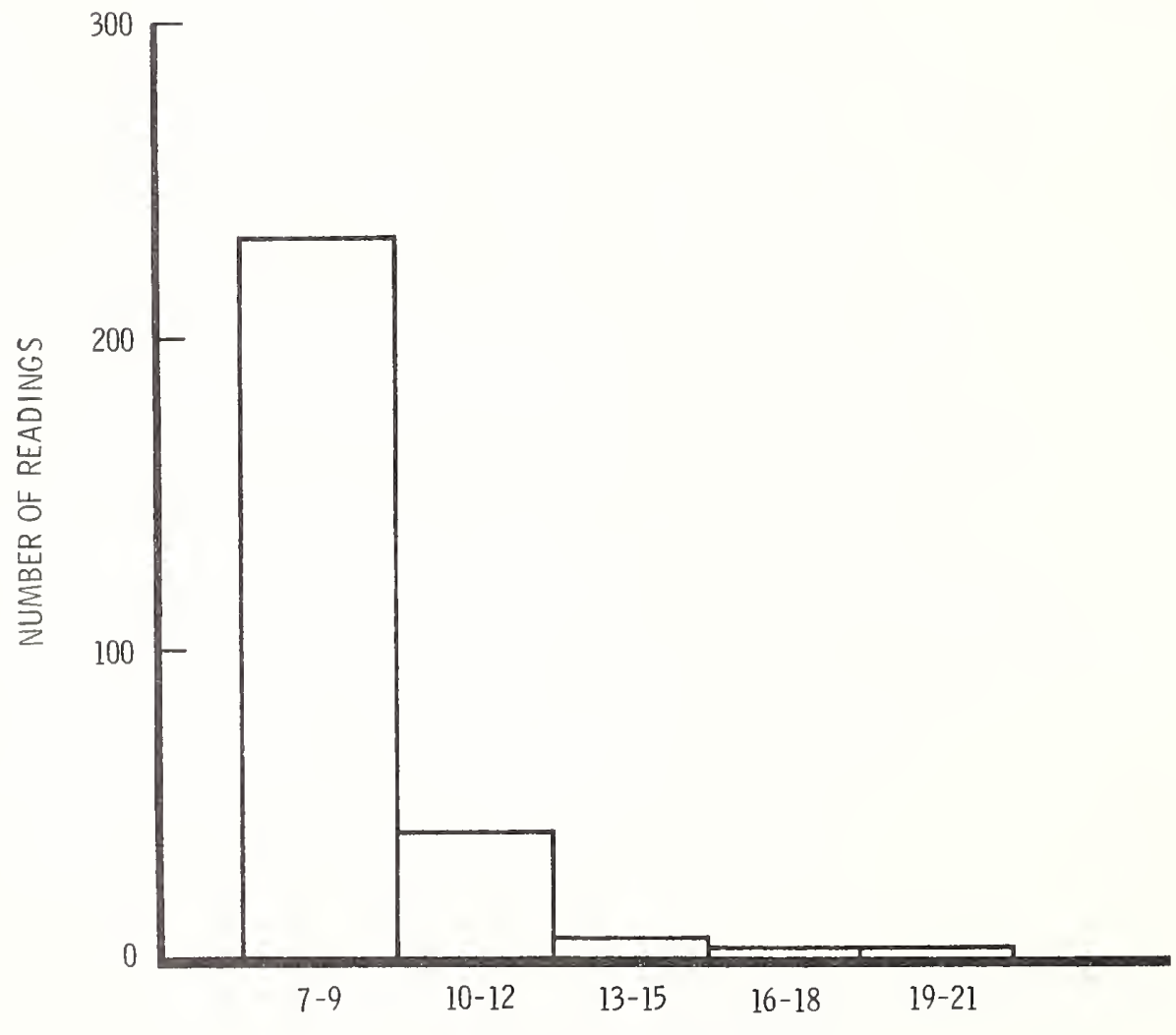

Figure 4.--Distribution of moisture content determinations made on kiln-dried lodgepole pine studs cut from dead trees. 


\section{CONCLUSIONS}

These studies show that for both western white pine and lodgepole pine the moisture content of lumber made from dead trees is about half the moisture content of lumber cut from green trees. The average moisture meter reading obtained from four packages of western white pine dimension lumber was 23.7 percent, and the average moisture content obtained from a subsample of this material by the ovendry method was 28.8 percent. The average moisture meter reading for the lodgepole pine studs was 16.5 percent, and the weighted average moisture content based on ovendried test sections was 22.7 percent. The difference in the moisture meter readings and ovendry test results can be attributed to (1) the reduced reliability of moisture meter readings above 25 percent; (2) the fact that the meter readings were not always adjusted for temperature or species; and (3) the number of readings that exceeded the scale maximum in the lodgepole pine study but were recorded as the scale maximum.

The moisture distribution specimens showed there was only a slight moisture gradient in the dead tree lumber. The average difference between the shell and the core was less than 2 percent moisture content for both species. Also, neither the dead white pine nor the dead lodgepole pine lumber had any significant amount of drying stress. Out of 93 white pine test sections, 61 remained straight, 26 showed some casehardening, and 6 showed some reverse casehardening. Of the 22 lodgepole pine test sections, 19 remained straight, and 3 showed a small amount of casehardening.

As a result of the relatively low moisture content, absence of drying stresses, and low moisture gradient, the drying schedule used to dry lumber from dead trees should be about half the time required to dry green tree lumber. These schedules could use higher initial drying temperatures. Avoiding excessive drying will reduce energy costs as well as prevent degrading of material by overdrying.

\section{RECOMMENDATIONS}

It is impossible to make hard and fast rules for drying lumber from dead trees because of the variability in trees from different areas and in milling equipment and procedures. Furthermore, if only an occasional dead $10 \mathrm{~g}$ is milled, the present practice of mixing the dead with green lumber and using the green lumber drying schedule is satisfactory. But if a sufficient quantity of dead lumber is produced to justify the sorting and use of a special drying schedule, greater efficiency will result. For the mill that does produce a quantity of dead lumber, some experimentation will probably be necessary to determine the optimum drying conditions. The study results reported in this paper indicate that the drying time could and should be reduced by at ieast 50 percent (based on the moisture content of the dead lumber). 
We suggest that the kiln operator determine the initial average moisture content of a kiln charge by testing 20 to 50 boards, selected at random, with both moisture meter and the ovendry test nethod. These data can then be used to prepare a graph relating the moisture meter value to the oven test values (fig. 5). Thereafter, only moisture meter readings will be needed to determine the true average moisture content of the charge.

When a charge of dead lumber is ready to be kiln dried, the kiln operator should measure the moisture content of 50 to 100 boards in the charge with a moisture meter. Using the average of these readings he can determine the true average moisture content from the graph and then select the initial drying conditions by referring to the guides contained in the Dry Kiln Operator's Handbook (Rasmussen 1961) for that particular species, thickness, and grade of lumber. By taking postdrying moisture meter readings and evaluating the quality of the dried, surfaced lumber, the kiln operator can determine if any further changes in the drying schedule are desirable.

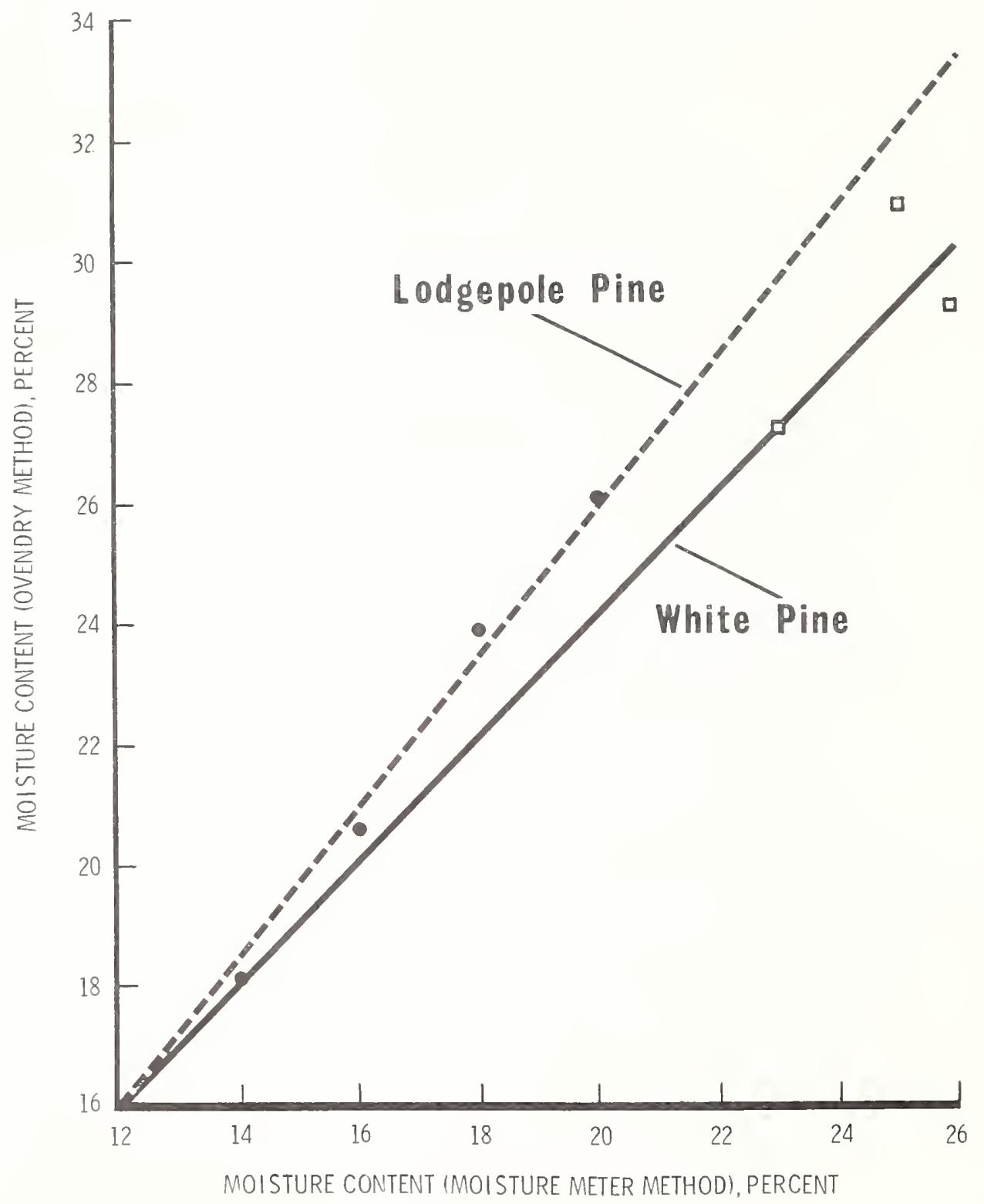

Figure 5.--ReZationship between moisture meter readings and true moisture content as determined by ovendry method. 


\section{PUBLICATIONS CITED}

Forest Products Laboratory, Forest Service, USDA.

1974. Wood handbook: wood as an engineering material. U.S. Dep. Agric. Handb. 72

(rev.). U.S. Gov. Print. Off, Hashington, D.C.

James, W. L.

1975. Electric moisture meters for wood. USDA For. Serv. Gen. Tech. Rep. FPL-6, For. Prod. Lab., Madison, Wisc.

McMillen, J. M.

1968. Transverse strains during drying of 2-inch ponderosa pine. USDA For. Serv.

Res. Pap. FPL-83. For. Prod. Lab., Madison, Wisc.

Rasmussen, E. F.

1961. Dry kiln operator's manual. U.S. Dep. Agric. Handb. 188. U.S. Gov. Print. Off., Washington, D.C. 
Headquarters for the Intermountain Forest and Range Experiment Station are in Ogden, Utah. Field programs and research work units are maintained in:

Billings, Montana

Boise, Idaho

Bozeman, Montana (in cooperation with Montana State University)

Logan, Utah (in cooperation with Utah State University)

Missoula, Montana (in cooperation with University of Montana)

Moscow, Idaho (in cooperation with the University of Idaho)

Provo, Utah (in cooperation with Brigham Young University)

Reno, Nevada (in cooperation with the University of Nevada) 
Lowcry, David P., and Allen L. Hearst, Jr.

197\%. Moisture content of lumber produced from dead western white pine and lodgepole pine trees. USDA For. Serv. Res. Pap. INT212, 11 p. Intermt. For. and Range Exp. Stn., Ogden, Utah 34401.

Moisture content of lumber from dead western white pine and lodgepole pine trees was determined using both a moisture meter and the ovendry test method. For both speeies, the moisture eontent of lumber from dead trees was about half that reported for green lumber. The kiln drying time for lumber made from dead trees should be about half the time required to dry green lumber.

KEYWORDS: western white pine, lodgepole pine, dead trees, lumber moisture content, kiln drying schedule.

Lowery, David P., and Allen L. Hearst, Jr.

197\$. Moisture content of lumber produced from dead western white pine and lodgepole pine trees. USDA For. Serv. Res. Pap. INT212, 11 p. Intermt. For. and Range Exp. Stn., Ogden, Utah $\$ \downarrow t 01$.

Moisture content of lumber from deadwestern white pine and lodgepole pine trees was determined using both a moisture meter and the ovendry test method. For both species, the nroisture content of lumber from dead trees was about half that reported for green lumber. The kiln drving time for lumber made from dead trees should be about half the time required to dry green lumber.

KEIWORDS: western white pine, lodgepole pine, dead trees, lumber moisture content, kiln drying schedule. 
NATIONAL AGRICULTURAL LIBAARY

|. || |. | | | ||

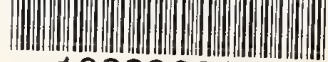

1022966182

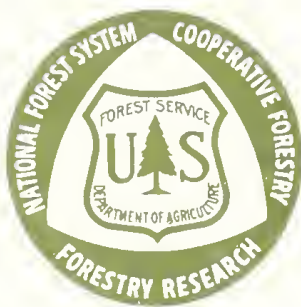

FOREST RESIDUES UTILIZATION DESTILIZATION

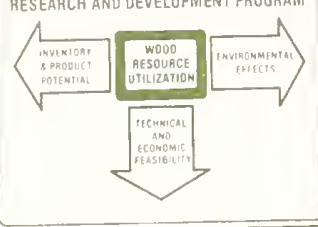

